\title{
メトへモグロビンの還元機序に関する研究 Studies on the Reduction of Methemoglobin
}

\author{
東京慈恵会医科大学公衆衞生学教室 \\ 山村行夫 \\ Yukio Yamamura \\ Department of Public Health, Tokyo-Jikeikai School of Medicine
}

\begin{abstract}
緒 言
芳香族ニトロ，アミド化合物を 用いる染料，化学薬 品, 爆薬工場などにみられる瞕業性中毒としてのメトへ モグロビン血症はかなり古くから注意されてきた。本症 はフェナセチン, スルファミン, 次硝酸蒼鈶, 硝酸アン モニウムなどの薬物を投与した際, あるいは不良な染色 毛布, スタンプインク11, ランドリーマークに接触した 際にもみられる。硝酸塭を多く含む食物をた流薬物の捸 取は腸内細菌丵の作用で亜硝酸塩を形成し 本症を生ず る。症例報告として述べられているなかには硝酸塩を多 量に含む飲用水を常用した乳児が本症を呈した例が認め られた2)。さてメトへモグロビン(以下 MetHb と略す) とはへモグロビン(以下 $\mathrm{Hb}$ と略す)の配合簇中の $\mathrm{Fe}^{++}$ 原子が酸化されて $\mathrm{Fe}^{+++}$原子に変えられたものである。 $\mathrm{Hb}$ の酸素化あるいは COとの結合には鉄原子が $\mathrm{Fe}^{++}$ であることが必要であり，したがつて MetHb の形では 酸素の運搬力はなく, 不活性 $\mathrm{Hb}$ と呼ばれている。上記 のような原因が加わり Hbに対する MetHb の割合が増 加すると当然組織への酸素供給注障害され組織は酸素欠 その状態となる。久保田 ${ }^{3}$ は MetHb による酸素久乏症 状の出現について全 $\mathrm{Hb}$ 量の $20 \%$ までは無害であり, 40 \%で酸素久乏症状が出現し，60〜 75\%では生命に危険で あると論じている。本症の治療に関する研究は主に先天 性 MetHb 血症を対象として進められて打り, 本症に対 するアスコルビン酸の有効性は Lian et al.4, ${ }^{4}$ ) 多くの研究がある。Hauschild ${ }^{6)}$ 芯酸化還元色素である メチレン青が MetHb 形成を伴なう中毒症状を軽減する ことを指摘してから, Wendel ${ }^{7)}$, Bodansky et al. ${ }^{87}$ とよ クメチレン青の有効性は広く推奨されている。てれらの 報告者はメチレン青が単独に Hb に加えられるとき, MetHb 部分の還元は著しく促進されるという。最近
\end{abstract}

Mangelsdorff" は MetHb 血症の場合の治療を総括して いるが, 彼はメチレン青で治療した例に心電図所見に異 常を認めたてとを報告し，MetHb 形成が軽度であれば 糖液を飲用せしめ, 医師の注視下で充分な安静をとらせ るととが治療の根本であると結論し，メチレン青の使用 は細心の往意が払わるべきであると述べている。MetHb 消失の割合は種族差，個体差がきわめて大きく，実験動 物の結果をそのまま臨床例に応用することは危険であ る。MetHb の還元機序に関しては既に Kiese ${ }^{10-12)}$, Gibson ${ }^{13)}$, Gutmann et al. ${ }^{14)}$ の詳細な研究があるがま だ充分解明されてはいない。著者は草食動物としてはウ サギ赤血球を,雑食動物としてはヒト,イヌ赤血球を用い MetHb の還元機序を 検討した 結果特に赤血球の解糖作 用との間に興味ある知見を得たので報告する。

\section{測定方法}

\section{I. 血中 MetHb の定量}

a) 原 理

2 種以上の成分よりなる溶液の吸光係数は, 各成分に 干渉作用がないとすれば, その各々の吸光係数の和に等 しい。

$$
E t=E_{1}+E_{2} \cdots \cdots \cdots \cdots \cdots \cdots(1)
$$

単位濃度, 単位厚さの溶液を一定波長で測定した吸光係 数を 特異的吸光係数として自己の比色計で測定してお く。濃度と被検溶夜の吸光係数々の間には次の関係がな りたつ。

$$
\mathrm{X}=\mathrm{E} / \mathcal{E}_{\mathrm{x}} \cdots \cdots \cdots \cdots \cdots \cdots(2)
$$

$\mathrm{x}$ は濃度, $\mathrm{E}$ はその溶液の吸光係数, $\mathrm{x} \mathrm{x}$ は成分 $\mathrm{x}$ の 特異的吸光係数である。

被検溶夜が 2 種成分からなる場合に各成分の濃度は 2 波長に扔ける各成分の特異的吸光係数がわかると Vie$\operatorname{rordt}^{15)}$ の連立方程式を用い算出することができる。 
$\operatorname{Eam}=\mathcal{E}$ ax $\mathrm{X}+\mathcal{E}$ ay $\mathrm{Y} \ldots \ldots \ldots \ldots(3)$

$\mathrm{Ebm}=\mathcal{E} \mathrm{bx} \mathrm{X}+\mathcal{E}$ by $\mathrm{Y} \ldots \ldots \ldots(4)$

(3) と (4) から

$\begin{aligned} \mathrm{X} & =\frac{\mathcal{E} \mathrm{by} \cdot \mathrm{Eam}-\mathrm{Ebm} \cdot \mathcal{E} \mathrm{ay}}{\mathcal{E} \mathrm{by} \cdot \mathcal{E} \mathrm{ax}-\mathcal{E} \mathrm{ay} \cdot \mathcal{E} \mathrm{by}} \cdots(5) \\ \mathrm{Y} & =\frac{\mathcal{E} \mathrm{ax} \cdot \mathrm{Ebm}-E \mathrm{Eam} \cdot \mathcal{E} \mathrm{bx}}{\mathcal{E} \mathrm{by} \cdot \mathcal{E} \mathrm{ax}-\mathcal{E} \mathrm{ay} \cdot \mathcal{E} \mathrm{bx}} \cdots(6)\end{aligned}$

Eam....波長 a での被検溶液の吸光係数

$\mathrm{Ebm} \cdots \cdot$...波長 b での被検溶液の吸光係数

$\mathcal{E}$ ax …波長 $\mathrm{a} て ゙ の$ 成分 $\mathrm{x}$ の特異的吸光係数

$\mathcal{E}$ ay $\cdots$...波長 a での成分 y の特異的吸光係数

$\mathcal{E} \mathrm{bx} \cdots \cdot$ 波長 $\mathrm{b}$ での成分 $\mathrm{x}$ の特異的吸光係数

$\varepsilon$ by …波長 b での成分 $\mathrm{y}$ の特異的吸光係数

$\mathrm{X}, \mathrm{Y}$ 虫成分 $\mathrm{x}, \mathrm{y}$ の未知濃度を示す

被検液が 2 種の有色物質の混合夜であり, そのうちい ずれか一方の物質の濃度が知りたい。この際混在物質の 濃度に変化を与えずに被検物質の吸光係数の夕変える方 法があれば操作は一層簡単になる。すなわち次の式が成 立する。

(3), (4) 式にならい,

$\mathrm{Eam}=\mathcal{E}$ ax $\mathrm{X}+\mathcal{E}$ ay $\mathrm{Y} \ldots \ldots \ldots(7)$

$\mathrm{Eam}^{\prime}=\mathcal{E}_{\mathrm{ax}^{\prime}} \mathrm{X}+\mathcal{E}$ ay $\mathrm{Y} \ldots \ldots \ldots(8)$

(7), (8) 式より,

$$
\mathrm{X}=\quad \begin{gathered}
\text { Eam }- \text { Eam }^{\prime} \\
\mathcal{E} \mathrm{ax}-\mathcal{E} \mathrm{ax}^{\prime}
\end{gathered}
$$

Eam…波長 $\mathrm{a}$ での被検溶液の吸光係数

$\mathrm{Eam}^{\prime} \cdots$ …波長 $\mathrm{a}$ での上記溶液について被検成分 $\mathrm{x}$ 在 $\mathrm{x}^{\prime}$ に変えた場合の吸光係数

$\mathcal{E} \mathrm{ax} \cdot \cdots$. 波長 $\mathrm{a} て ゙ の$ 成分 $\mathrm{x}$ の特異的吸光係数

$\mathcal{E}$ ay …波長 a での混在成分 $\mathrm{y}$ の特異的吸光係数

$\mathcal{E} \mathrm{ax}^{\prime} \cdots$...波長 $\mathrm{a} て ゙$ 成分 $\mathrm{x}$ を $\mathrm{x}^{\prime}$ に変えた場合の特 異的昅光係数

$\mathrm{X}, \mathrm{Y}$ はそれぞれ成分 $\mathrm{x}, \mathrm{y}$ の濃度を示す。

ただしこの場合成分 $\mathrm{x}$ の濃度が色調を変えられた前 後で変化しないこと, ならびにこの成分 $\mathrm{x}$ に対する操作 が混在成分 $\mathrm{y}$ に影響しないととが必要である。以上の操 作は Michel ${ }^{16 i}$ が $\mathrm{Hb}-\mathrm{O}_{2}$ と MetHb 混合液の MetHb の 测定に用いた方法であるが，乙の方法は (Eam-Eam') の差が大きい波長を選べば単一波長領域の測定のみで被 検成分の濃度が測定できてきわめて便利である。MetHb 快 pH 7 以下で $630,500,405 \sim 407 \mathrm{~m} \mu$ に吸収㥛大 を有する。MetHb 溶液にどく少量の結晶 $\mathrm{KCN}$ 老添加 すると，鉄原子と $\mathrm{CN}^{-}$は定量的に結合し MetHb 濃紊 に変化を与えずに $630 \mathrm{~m} \mu$ の山が消失し MetHb-CN の滑らかな曲線に変る。この際 $\mathrm{Hb}$ と $\mathrm{CN}^{-}$の結合は
ごく緩慢であり $50^{\circ} \mathrm{C} て ゙ 30$ 分を要するといわれる17。すな わち著者の測定ではあまり障害とはならなかつた。

b) 基本的操作

容量 $12 \mathrm{ml}$ 遠沈管に M/60燐酸緩衝液 (pH 6.6) $10 \mathrm{ml}$ をとり, ヘパリン加血液の $0.1 \mathrm{ml}$ を加える。さらにサ ポニン小刃尖量を加えて充分溶血を助け, 3,000 r.p.m., 10分間で血球礎質を 沈澌除去する。その上清学 直ちに Beckmann 型日立光電比色計在使用し, 波長 $630 \mathrm{~m} \mu$, スリット幅 0.06 を用いて測定を抢てなう。使用したキュ 一ベットは $1.0 \mathrm{~cm}$ 幅のものである。Blankとしては蒸 溜水老用いた。

c) 定量式の作成

$16 \mathrm{~g} / \mathrm{dl}$ 濃度 MetHb の基準液を用い,との $0.1 \mathrm{ml}$ を 上.記緩衝液の10 $\mathrm{ml}$ に稀釈する。との溶液について, 波 長 $630 \mathrm{~m} \mu$ で上記のごとく吸光度 $\mathcal{E a x}$ を求める。つい で同じキューベットに結晶 KCN (Merk 製) の小刃尖 量を添加すると MetHb の赤褐色は MetHb-CN の鮮紅 色に変る。そこて 5 分間静置後再び $630 \mathrm{~m} \mu$ で吸光度を 测定し $\mathcal{E a x ^ { \prime }}$ を求める。その值を（9）に代入すると，

$$
\mathrm{X}=\frac{\mathrm{Eam}^{-E_{\text {Eam }}}}{0.44-0.054}=\frac{\mathrm{Eam}-\mathrm{Eam}^{\prime}}{0.386} \cdots(10)
$$

となる。

資料中 MetHb 濃度を測定するには（10）式で得た值 に $16 \mathrm{~g}$ を乗ずると MetHb gm/血夜 $100 \mathrm{ml}$ として算出 することができる。実際の測定に際して注意すべきとと

Fig. 1 Spectrophotometric Curves of MetHb \& MetHb-CN

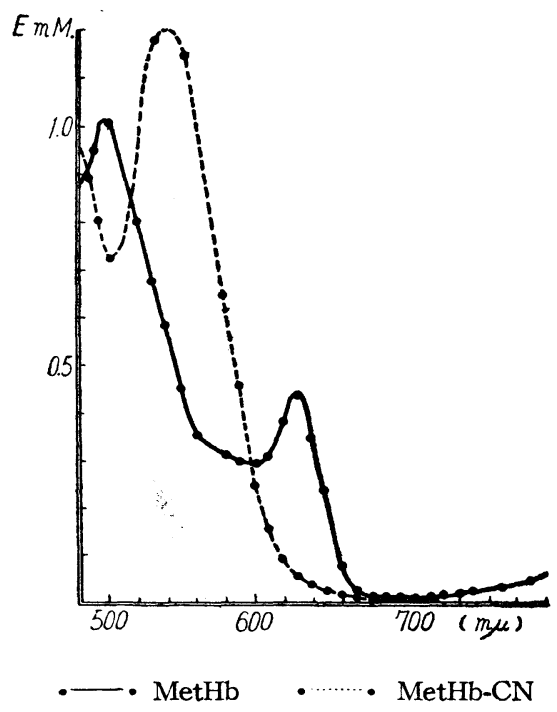


は，一度使用したキューベットは次の使用の前には充分 に洗條することである。もしキューベット中に KCN が残つていると, 次に MetHb 被検溶液を入れた際に MetHb-CN を形成し，思わぬ誤差を生ずることがあ る。

\section{II. ブドー糖の定曋法}

Somogyi-Nelson 法 $^{18)}$ によつた。

\section{III. 酸酸の定量法}

Baker \& Summerson 法 ${ }^{19}$ によつた。

\section{IV. 焦性プドー酸の定量法}

Friedmann \& Haugen 法20)によつた。

\section{V. アスコルビン酸の定量法}

藤田一老名原法 ${ }^{21}$ によつた。

\section{2, 3 の試薬について}

リンゲル液の処方は $\mathrm{NaCl} 0.9 \%, \mathrm{KCl} 0.4 \%, \mathrm{CaCl}_{2}$ $0.011 \%, \mathrm{Na}_{2} \mathrm{HPO} 40.177 \%, \mathrm{pH} 7.4$ ならびに $\mathrm{NaCl} 0.9$ $\%, \mathrm{KCl} 0.02 \%, \mathrm{CaCl}_{2} 0.02 \%$, phosphate $\left(\mathrm{Na}_{2} \mathrm{HPO}_{4}\right.$, $\left.\mathrm{NaH}_{2} \mathrm{PO}_{4}\right) \quad 0.1 \mathrm{M}, \mathrm{pH} 7.4$ を用いたがいずれの場合も 差はなかつた。

Tyroid 氏処方は $\mathrm{NaCl} 0.8 \%, \mathrm{KCl} 0.02 \%, \mathrm{CaCl}_{2}$ $0.02 \%, \mathrm{MgCl}_{2} 0.01 \%, \mathrm{NaH}_{2} \mathrm{PO}, 0.005 \%, \mathrm{NaHCO}_{3}$ $0.1 \%$ ある。

ATP ソーダは興和化学製, DPN は第一化学製を用い た。

\section{実験方法ならびに結果}

\section{I. ウサギ赤血球内の MetHb 還元速度について}

赤血球浮遊液に亜硝酸塩を加えると $\mathrm{Hb}$ は酸化されて MetHb に変る。こうしてできた MetHb も環境液が適

Fig. 2 MetHb Reduction (Rabbit)

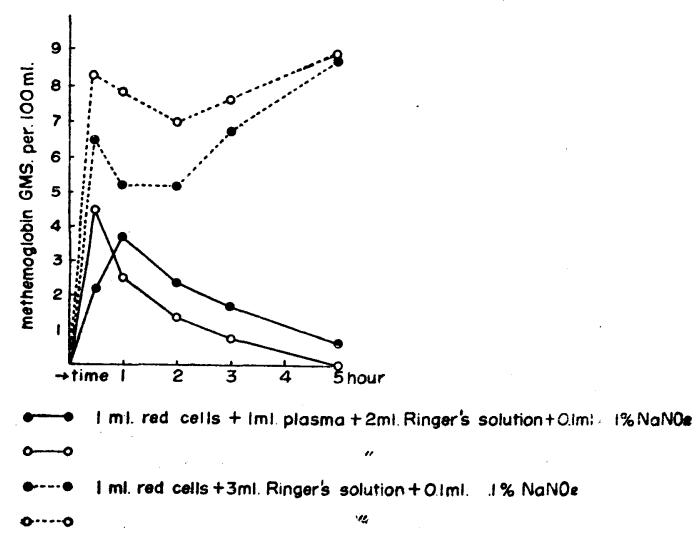

当であれば，次第に還元され，還元型 $\mathrm{Hb}$ となり活性を とり戻すのである。このような還元作用が環境液の還元 物質によるものであるか, また㤸血球内に含まれる還 元物質の機能に基づくものであるかを知るためまず次の ごとき実験を試みた(第 2 図)。

$2.5 \mathrm{~kg}$ 雄ウサギの静脈血をへパリン処理のもとに 採血し, 遠心沈澱で血球層と血漿層に分ける。容量 30 $\mathrm{ml}$ の三角コルベンを用い，一方には赤血球 $1 \mathrm{ml}$, 血漿 $1 \mathrm{ml}$, 抢よびリングル液 $2 \mathrm{ml}$ を混合する。他方のコル ベンには赤血球 $1 \mathrm{ml}$, リンゲル夜 $3 \mathrm{ml}$ 学混合する。次 に両コルベンを $37^{\circ} \mathrm{C}$ 恒温槽中で軽く振璗し, フラスコ内 外の温度を平衡させ, そとで $1 \% \mathrm{NaNO}_{2} 0.1 \mathrm{ml}$ を加 えゴム栓を施して incubate を続ける。実駼流好気的条 件下で 5 時間にわたつて施行し, 資料は 1 時間ごとに採 取し，上記の方法で MetHb 濃度を測定した。実線は環 境液に血漿を加えた場合であり，5時間後には MetHb のほとんどが消失している。点線は環境夜がリンゲル 液のみの場合であり，乙の際には incubate の初期に MetHbが 還元され一時減少するのであるが，その後は MetHb の含有量がぞんぞん増加して行くことが観察さ れる。この実験の結果は, intact 赤血球内で MetHb が還 元されるには環境夜に血槳が必要であるととを示唆する ものである。血漿環境で MetHb の還元が速やかである といらことは，血墏中に含まれるいかなる物質の作用に よるものであるのか, 血漿中に含まれる還元物質として は,アスコルビン酸, ブドー糖, 果糖あるいはその大部分 は酸化型であるが,グルタチオンなどが挙げられる。アス コルビン酸は紫外線により酸化されることが知られてい る。第 3 良はあらかじめ紫外線を照射した血墏と未照射 の正常血漿を用いた場合について, 赤血球の MetHb 還 元速度に差があるかどうかを比較検討したものである。

特に照射血漿については紫外線照射ののち血漿のアス コルビン酸含有量を藤田-老名原法 ${ }^{21}$ で測定し, 還元型 アスコルビン酸をまつたく含まないととを確めてから実 験に用いた。以下 MetHb 血球という場合は, 動物よりへ パリン処理のもとに採血し，のち血漿を除去して赤血球 の及を $1 \% \mathrm{NaNO}_{2}$ リングル液中に浮遊し，乙の液を 37 ${ }^{\circ} \mathrm{C}$ 恒温槽中で $10 \sim 20$ 分間 incubate し, 次にリングル 液で $3 \sim 5$ 回洗條して $\mathrm{NaNO}_{2}$ を除去し調製した赤血球 についての名称である。実線は血液 $2 \mathrm{ml}$ 相当 MetHb 血球に正常血漿を加え全量 $4 \mathrm{ml}$ としたものであり，点 線は血液 $2 \mathrm{ml}$ 相当 $\mathrm{MetHb}$ 血球伤紫外線照射血嶈を加 え全量を $4 \mathrm{ml}$ としたものである。との結果環境夜に照 射血墏を用いた場合の MetHb 還元速度が対照の未照射 
Fig. 3 Effect of Irradiated Plasma on MetHb Reduction (Rabbit)
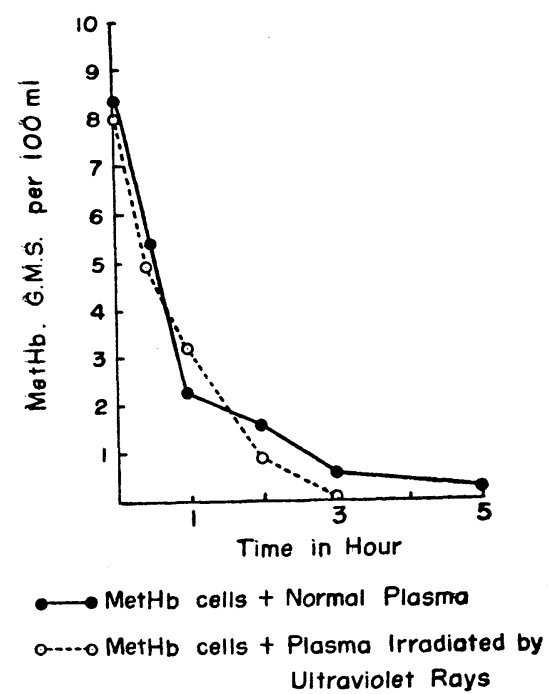

㿼漿を用いた場合よりも遅れるということはなかつた。 赤血球は他の組織よりもグルタチオンを多量に含有して 抢り ${ }^{221}$ ，デハイドロアスコルビン酸はグルタチオンによ り還元されアスコルビン酸に戻る ${ }^{23)}$ 。一方酸化型グルタ チオンはブドー糖を基質として, グルタチオン還元酵素 の作用で再還元されるのである ${ }^{24)}$ 。 2,3 の研究者は循 環赤血球中に生じた MetHb を生理的に還元するもの は, 赤血球中に含まれるアスコルビン酸ーグルタチオン

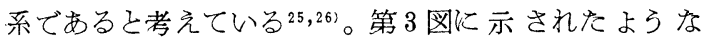
結果ももし酸化されたアスコルビン酸でも incubate 中に赤血球中深透し，そこで大量に含まれるグルタチ オンで賦活されると考えるならばアスコルビン酸の作用 であると考えることができる。そこでこのような推論の もとに，リンゲル液に $10 \mathrm{mg} / \mathrm{dl}$ アスコルビン酸ならび そグルタチオン還元の基質としてブドー糖の $100 \mathrm{mg} / \mathrm{dl}$ を加え, これを前回同様に紫外線を照射し, アスコルビ ン酸を酸化してのち MetHb 血球の環境液として用い還 元速度を測定した。との結果は対照のブドー糖リンゲル 液との間に差はなく，したがつて以上の推論は否定され た。d-ブドー糖, d-果糖, d-マンノース, d-ガラクトー ス，あるいは乳酸を含むリンゲル液を用いると MetHb が還元されるととは Kiese ${ }^{11)}$, Wendel ${ }^{26)}$, Spicer ${ }^{27)}$ に より報告されている。次の央験はこの点を追試し,ブド 一糖, 乳酸, 果糖 1.6 ヂ燐酸ならびに焦性ブドー酸を基 質とした場合の MetHb 還元速度を比較検討した。
Fig. 4 Effect of Various Substrates on MetHb Reduction (Rabbit)

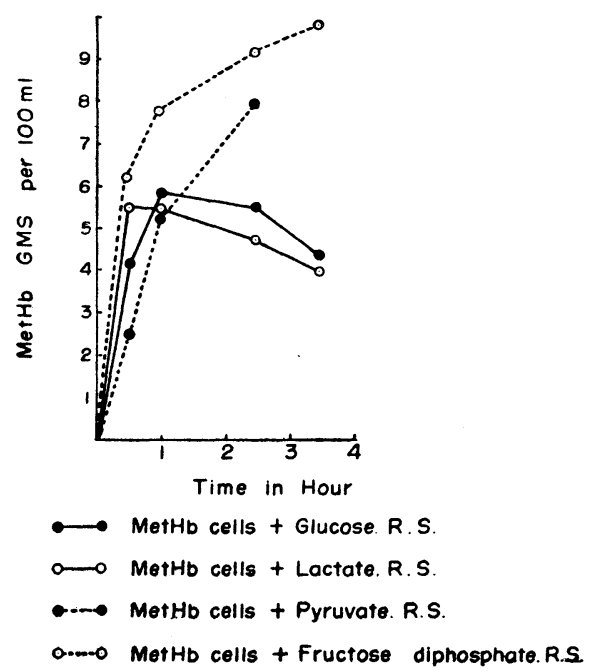

第 4 図は血液 $2 \mathrm{ml}$ 相当赤血球を基質の各々 $100 \mathrm{mg} /$ dl を含むリンゲル液中に浮遊し全量を $4 \mathrm{ml}$ としたもの に最初の実験と同様に $1 \% \mathrm{NaNO}_{2}$ の $0.1 \mathrm{ml}$ を添加し 各時間ごこの MetHb 濃度を測定したものである。ブド 一糖, 乳酸が基質である場合には $\mathrm{Hb}$ の酸化は防がれ, 緩慢ではあるが MetHb は還元されるととがわかる。基 質が果糖 1.6 千辚酸および焦性ブドー酸であると還元 はみられない。糖の中間代謝産物である環境液中の燐酸 エステルが赤血球で代謝されないというととから，赤血 球膜はこのような橉酸エステルは透過しないと考えられ ている ${ }^{28}$ 。この実験で, 果糖 1.6 ヂ憐酸では還元のみら れない事実はやはりとの燐酸エステルが赤血球内に入る ことができないためと考える。さてブドー糖あるい乳 酸が環境液中に含まれていると浮遊赤血球内の $\mathrm{MetHb}$ は緩慢ではあるが還元されるととがわかつた。ウサギ血 漿中にはブドー糖は約 $100 \mathrm{mg} / \mathrm{dl}$, 乳酸は20 mg/dl 前後 含まれている。環境液が $200 \mathrm{mg} / \mathrm{dl}$ ブドー糖リンゲル液 を用いた場合と血漿である場合の MetHb 還元速度を第

Table 1

\begin{tabular}{|c|c|c|c|c|}
\hline \multirow{2}{*}{ No. } & \multicolumn{4}{|c|}{ medium } \\
\hline & \multicolumn{2}{|c|}{ plasma } & \multicolumn{2}{|c|}{ glucose Ringer } \\
\hline 1 & \multicolumn{2}{|c|}{$5.32 \mathrm{~g} \% / 3 \mathrm{hr}$} & \multicolumn{2}{|c|}{$0.98 \mathrm{~g} \% / 3 \mathrm{hr}$} \\
\hline 2 & 8.92 & $\prime \prime$ & 1.46 & $\prime \prime$ \\
\hline 3 & 7.23 & $\prime \prime$ & 2.62 & $\prime \prime$ \\
\hline 4 & 11.08 & $\prime \prime$ & 3.70 & $\prime \prime$ \\
\hline
\end{tabular}


1 表に示す。これは 3 時間に還元された MetHb の $\mathrm{g} \%$ である。

ここで明らかなようにウサギでは, in vitro の観察で 環境液が血漿である際にの及赤血球の MetHb をほぼ完 全に還元することができるのである。

次に血漿中に含まれるブドー糖, 乳酸の MetHb 還元 物質こしての役割について検討した結果を述べる。

a） 解糖作用の中間においてグリセリンアルデヒド 3 繗酸が酸化されるこきは赤血球内の焦性ブドー酸は還 元され乳酸を生成する。との間の酸化還元には 助酵素 $\mathrm{DPN}^{+}$が関与している。その間の大略は次のと括りであ る。

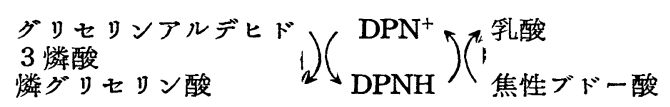

モノヨード酢酸は三炭糖燐酸脱水素醭素を強く阻害す る。血漿に $2 \times 10^{-3} \mathrm{M}$ モノョード酢酸を添加した場合の MetHb 還元は 3 時間後約 $55 \%$ 阻害された。Gibson ${ }^{13)}$ は ブドー糖リンゲル環境液中でのヒト赤血球内の Met$\mathrm{Hb}$ 還元は $2 \times 10^{-3} \mathrm{M}$ モノヨード酢酸の添加で $90 \%$ 阻 害されることを，さらにまた Spicer ${ }^{27)}$ は $10^{-5} \mathrm{M}$ モノヨ 一ド酢酸て70\%抑制されるととを報告している。血漿に モノヨード酢酸を加えると MetHbの還元が約 $55 \%$ 抑制 されるととは，乙の還元機序に三炭糖燐酸脱水素䤃素の 関与が重要であるととを物語るとともに，抑制を受けな い部分のあるととは乳酸酸化が関連するなどこれ以外の 過程が存在するととも考慮される。

Fig. 5 Effect of Plasma on MetHb Reduction [I] (Rabbit)

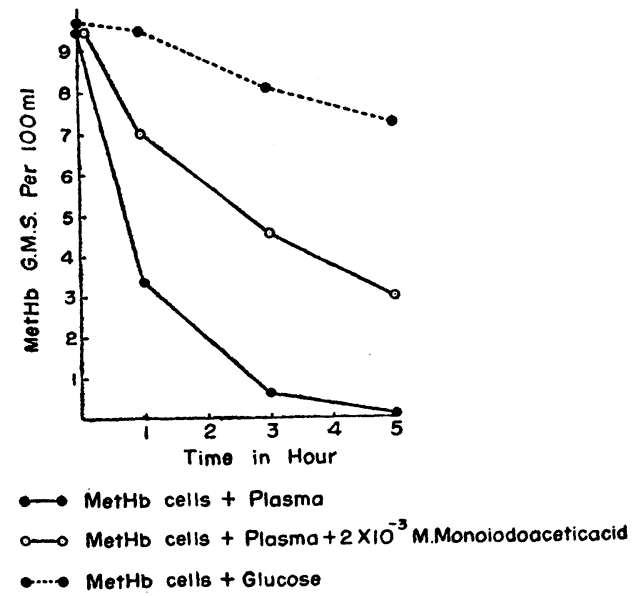

b）ブドー糖，果糖，マンノースなどの六炭糖はパン

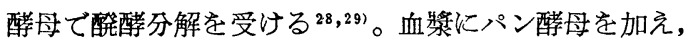
$37^{\circ} \mathrm{C}$ の恒温槽中で30分間 incubate し, その後, 遠心沈 垻により酵母を除去した血漿を環境夜として用いた場合 の MetHb 還元速度について測定した。この血漿は実験 にさきだち Somogyi-Nelson 法で還元性糖を 含有しな いととを確めてから用いた。この結果では 3 時間後の MetHb の還元量は $78 \%$ の阻害を受けた。

c) Brooks ${ }^{311}$ はウサギに亜硝酸塩を投与し MetHb を 形成させた場合，引続いて $1 \%$ ブドー糖液を $2 \mathrm{ml}$ 静脈 注射すると対照に比較し MetHb の消失が早まることを 報告して抢り，また Cox \& Wendel ${ }^{32)}$ はイ又赤血球に ついて in vivo 拉よび in vitro の実験で血糖が 40〜 $400 \mathrm{mg} / \mathrm{dl}$ の範囲では MetHb 還元速度への影響はみら れないと述ベている。著者は添加後ブドー糖濃度が 396 $\mathrm{mg} / \mathrm{dl}$ を示した血獎を環境液として用いその還元速度を 観察した。第 6 図に示すどとく，未添加血漿の場合との 間に差は認められない。したがつて，との所見から血漿

Fig. 6 Effect of Plasma on MetHb Reduction [II]

(Rabbit)

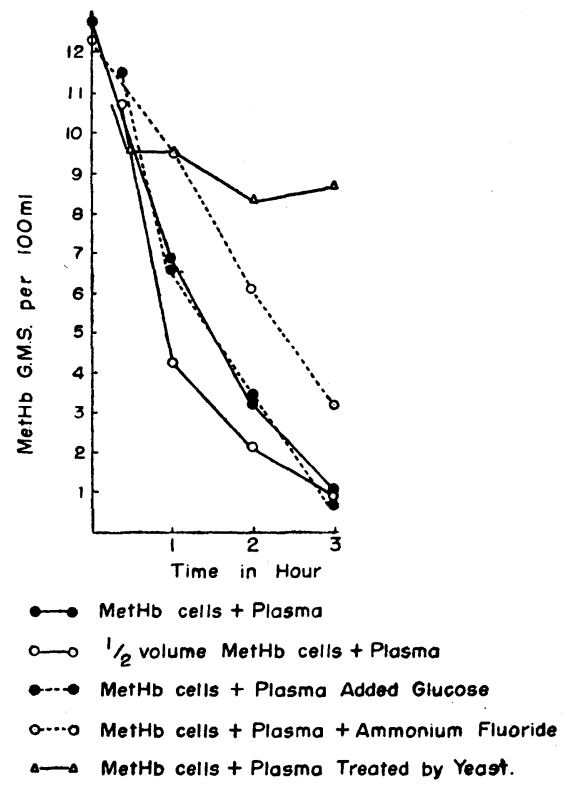

中のブドー 糖含有量がごく低濃度である場合を 除いて は, 環境液中のブドー糖濃度を増加させる操作のみで解 糖速度を促進し, その結果 MetHb 還元を早めるという ような簡単な機序を考えるととはできない。

d) MetHb 血球の量を减らして赤血球に対する血漿 
の割合を增せば還元速度はやや促進された。ブドー糖分 解の過程に基づく MetHb の還元能以赤血球内に含まれ る酵素系の機能により制限される。環境が血槳であるこ とが，とれら還元系にとりもつともょい代謝回転の条件 を提供するものと考える。

e)弗化物は $\mathrm{Mg}^{++}$と強く結合し Magnesium fluorophosphate を形成する。したがつて $\mathrm{Mg}^{++}$を必要とする エノラーゼ活性が弗化物の添加で阻害され，焦性ブド 一酸生成は減少し燐グリセリン酸が増加してくる ${ }^{33) 。 ~}$ Gibson $^{13)}$ の成績ではブドー糖リンゲル海を 環境夜に用 いた場合， $0.01 \mathrm{M}$ 弗化ソーダを添加しても MetHb の還元は阻害を受けないというが，これに反しShapot ${ }^{34)}$ は弗化ソータの阻害作用を認めている。また Drabkin ${ }^{35}$ ) は弗化ソータの阻害は焦性ブドー酸を添加して抢くと 防がれると報告している。著者は環境液として弗化アン モニウムを添加した血漿を用い，未添加血墏の場合と比 較して MetHb 還元能が約20\%阻害される結果を得た。

\section{II. ウサキ溶血液中 MetHb の還元について}

ブドー糖分解の中間代謝物質は大部分が嶙酸エステル である。これらの化合物は前述のょうに赤血球膜を透過 できない。そてで解糖作用のどの過程と関連して MetHb が還元されるのかを確めるには溶血系での実験を試みね ぼならない。

Fig. 7 Effect of Concentration of DPN on MetHb Reduction (Hemolysate)

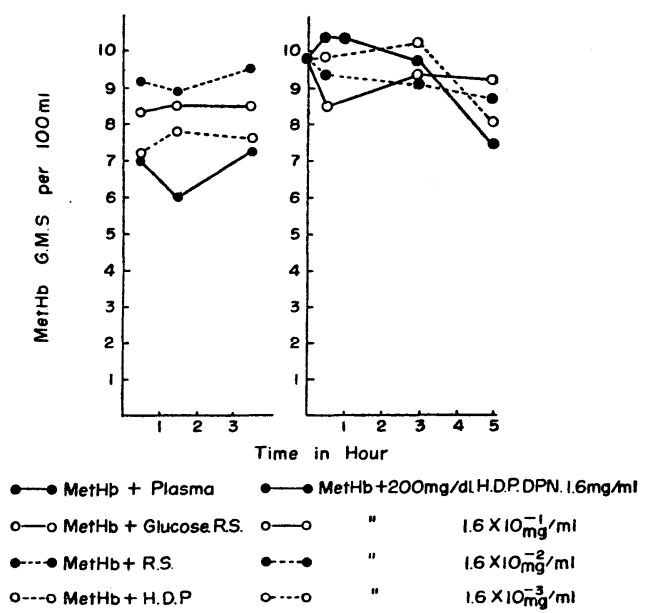

第 7 目,左側に示す実験では血漿， $200 \mathrm{mg} / \mathrm{dl}$ ブドー糖 リンゲル,リンゲル, $200 \mathrm{mg} / \mathrm{dl}$ 果糖 1.6 チ橉酸リンゲル のそれぞれの環境夜中で MetHb 血球に尗ポニンを加え て溶血し礎質を可及的に除いた各々についての MetHb
還元能を示す。いずれの場合にも還元を認めるととがで きなかつた。第7図，右側の実駼は MetHb 還元に招け る $\mathrm{DPN}^{+}$の役割を検討するために試みたものである。 基質として $200 \mathrm{mg} / \mathrm{dl}$ 果糖 1.6 チ燐酸を含む $1 / 15 \mathrm{M}$ 燐 酸緩衝液に DPN ソータを倍数稀釈で加え, この環境中 で MetHb 血球を溶血せしめ, その溶血系 MetHbの還 元に及ぼす $\mathrm{DPN}^{+}$濃度の影響を検討した。図に示され るょうにいずれも明らかな還元は認められず，したがつ て $\mathrm{DPN}^{+}$濃度との関係を追求するととができなかつた。 従来, 赤血球のブドー糖消費は溶血すると消失するとと が報告されている ${ }^{36}$, Gibson ${ }^{131}$ は溶血液中では MetHb の還元が起きないと述べているさててのように溶血に 伴ない還元能が失われる理由としては次のように考えて いる。赤血栈膜には ATP-ase, DPN-ase が含まれてい る。赤血球が溶血されるととれらの醏素は赤血球内の燐 酸代謝抢よび脱水素反応に必要な ATP, DPNを分解し てしまうのである。その結果は, 解糖作用は止まりこれ と関連する MetHb 還元能も失われる。Gutmann et al. 14) とし，この製剤を MetHb 溶夜に加えれ榙元作用が現 われることあるいは溶血にさきだちあらかじめニコチン アミドを加えておけば DPN-ase 作用が抑制されるので MetHb 還元が反られると述心゙, DPNH の関与を強調し ている。著者の奉験で還元作用がみられなかつた理由と しては次の 2 つを考えている。すなわち，基質である果 糖 1.6 于燐酸が解裂し脱水素々酸化的燐酸化により燐グ リセリン酸を生ずるまでに必要な醅素系が障害されるこ と,末たは解糖作用で生じた還元物質 (DPNH)が MetHb の還元に利用される間任位置する酵素系に障害が現われ るということである。

III. ウサキ赤血球の MetHb 還元時, ブドー糖，等 酸，焦性ブドー酸の消長について（第 8 因）

\section{a) ブドー糖}

実験材料は上記 MetHb 還元速度の測定に用いたと同 じフラスコ内血液から得たものである。MetHb 血球拉 よび対照正常赤血球による環境ブドー糖の消費量を図示 する。MetHb 血球の浮遊している環境液中のブドー糖 減少量注反応 5 時間でブドー糖リンゲル環境では $31 \mathrm{mg} /$ dl であり, 血漿環境では $48 \mathrm{mg} / \mathrm{dl}$ である。血漿環境で の減少は速やかである。

b) 乳 酸

哺乳動物の成熟赤血球はチトクロームあるいは TCA 回路系の酻素を保有せず，したがつて生活エネルギーの 供給はもつばら解糖作用に求めている。乳酸牥解梧作 
Fig. 8 Comparison of Glycolysis and MetHb Reduction (Rabbit)
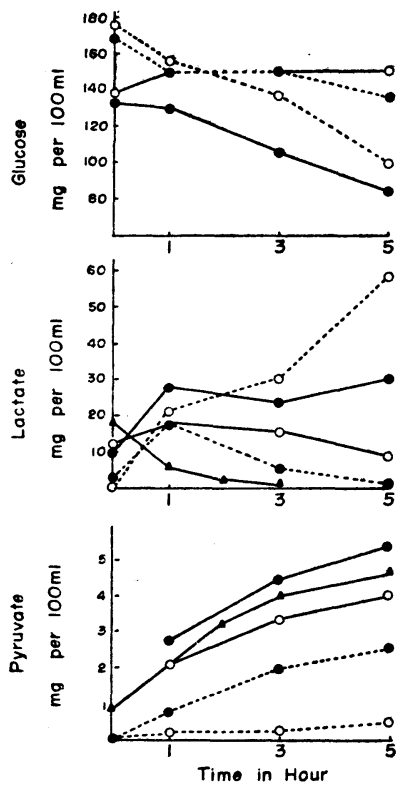

$\longrightarrow$ MetHb cells + Plasmo

$\multimap$ MetHb cells + Plasma $+2 \times 10^{-3}$ M. Monoiodoacetate

$\longrightarrow$ MetHb cells + Plasma + Ammonium Fluoride

-.... Meitho cells + Glucose RS.

o....- Normal cells + Glucose R.S.

用の終末産物であり，分解がきわめて緩慢であるために 解糖が進行するに伴ない血漿中に増加してくる。通常血 獎中乳酸の含有量は 10〜20 mg/d である。正常赤血球 を用いると乳酸は時間の経過に伴ない環境夜中に増加す る。MetHb 血球の場合では初期に一時増加するが，し かし環境がブドー糖リングル液であるととの増加した乳 酸も 5 時間後には消失する。血墏環境では実験前値と 5 時間値の差は僅少である。とのことはその生成と基質と しての利用が競り合つているためである。モノョード酢 酸添加血獎では増加はやや抑えられ, 弗化アンモニウム 添加血漿では乳酸の焦性ブドー酸からの生成がないため に血漿中に既存の乳酸が 3 時間後には完全に利用されつ くし消失する。

\section{c）焦性ブドー酸}

正常赤血球の代謝過程では焦性ブドー酸は還元され速 やかに乳酸を生成する。したかつて,血嶈中に遊離する焦 性ブドー酸の量はきわめてわずかであり，もしも赤血球 内に MetHb が多量に含まれていると血嶈中の焦性ブド 一酸は増加してくる。この測定に際しての資料採取法は
すべて前記同様の条件下でおてなつた。浮遊血球が正常 赤血球ならば 5 時間後でもほとんど增加はみられない。 これに反し, MetHb 血球が血漿環境に浮遊されている 場合は焦性ブドー酸の著しい増加を招いた。弗化アンモ ニウムあるいはモノョード酢酸を添加した血漿ではその 増加はややわずかである。環境がブドー糖リンゲル液で あれば焦性ブドー酸の増加性さらに少かつた。

\section{1ヌ赤血球内の MetHb 還元速度について}

体重10 kg 倠性イヌの静脈血を採取し, 遠心沈澱をも つて血球と血墏を分ける。血球層の表層にある白血球を 充分に除き，ウサギでおてなつたと同様に亜硝酸塩を加 えて in vitro で MetHbをつくり, MetHb 血球として 実験に用いた。アニリン中毒の MetHb 血球は同犬にア シリンの $5 \mathrm{cc}$ ⿸皮下注射し, in vivo で MetHb つつく り, 2 時間に採血し,以下上記同様に操作して実験に用い た。フラスコ内容は赤血球が 4 倍稀釈となるように環境 液をもつて稀釈したものである。用いた赤血球内 Met$\mathrm{Hb}$ 含有量注総色素量に対し, 亜硝酸塩処理て $70 \%$, ア シリン中毒で30\%であつた。アニリン中毒 MetHbにつ いての還元速度は 5 時間で血漿環境で $2.2 \mathrm{mg}$, ブドー 糖リンゲル環境で $1.1 \mathrm{mg}$ であり,亜硝酸塩処理 MetHb の場合ブドー糖リンゲル環境で $0.4 \mathrm{mg}$ といずれもウサ ギ赤血球 と比較し，きわめて緩慢であることを知つた (第 9 図)。

Fig. 9 MetHb Reduction (Dog)

MetHb Cells of Anilin Poisoning and Prepared by Nitrite

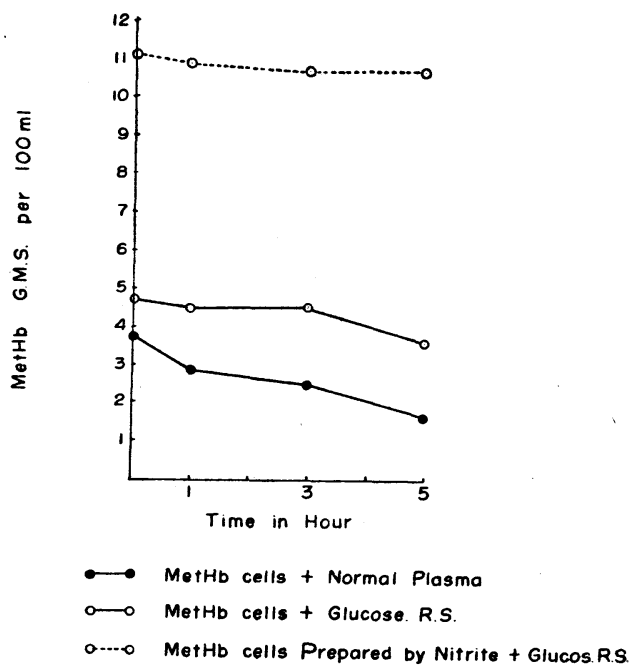




\section{V. イヌ赤血球の MetHb 罢元時, 乳酸，焦性フト 一酸の消長について}

a) 乳 酸

環境夜中の乳酸は時間の経過に伴ない添滀直線的に増 加する。 $200 \mathrm{mg} / \mathrm{dl}$ ブドー糖リンゲル液環境では正常赤 血球々 MetHb 血球間飞乳酸生成量の差はみられない。 血漿環境では MetHb 血球であるに拘らず乳酸生成注や や著しい。亜硝酸塩処理で MetHb か高濃度に形成され る場合は乳酸の生成はいくぶん低值を示した(第10図)。

Fig. 10 Glycolysis of MetHb Cells (Dog)

MetHb Cells of Anilin Poisoning and Prepared by Nitrite

Lactate
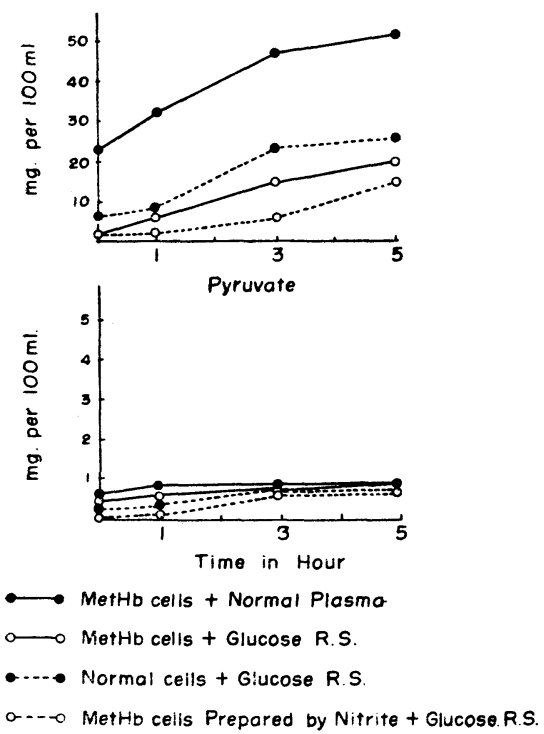

b) 焦性ブドー酸

赤血球内に MetHb が多量に形成される場合にウサギ 血液で反られた特徴ある所見は焦性ブドー酸が増加する ということであつた。しかるにイヌの場合では正常赤血 球と比較し MetHb 血球の焦性ブドー酸の増加量は環境 が $200 \mathrm{mg} / \mathrm{dl}$ ブドー糖リングル液であつても, あるいは 血漿を用いても, さらには MetHb 含有量が著しく違つ ていても, その増加量はほとんど同じ程度に多られるに すぎなかつた(第10図)。

\section{VI. ヒト, イヌ, ウサキ赤血球内 MetHb 還元速度 の比較}

ヒト,イヌ, ウサギ赤血球について前述の実験とその 後の 2,3 の実験を総括し,動物の種族差による還元能の 差異ならびに環境液, 特に血嶈環境の MetHb 還元に及
汸す影響に関して考察した。比較に用いた実験はすべて 亜硝酸塩でつくられた MetHb 血球についての成績であ り，還元速度を表わすためには実験前の MetHb 濃度に 対し $37^{\circ} \mathrm{C}$ 恒温槽で 3 時間 incubate したのち，還元され た MetHb 量を百分率で示し, 還元率として記述した。 実験対照はヒト健康青年男子 3 名, イヌ $10 \mathrm{~kg}$ 雄 1 匹, ウ サギ $2.5 \mathrm{~kg} \sim 3 \mathrm{~kg}$ 雄 8 羽を用い, 図に示した值はそれ ぞれの平均である。ヒトならびにイヌ赤血球の MetHb 還元は環境がブドー糖リンゲル液である場合と血漿であ る場合ではその差は少く，還元傾向はいずれも僅少であ つた。ウサギ赤血球にみられる所見はてれときわめて対 照的であり，それが血漿環境であれば実に MetHb の90 \%が還元される。しかしブドー糖リングル環境に浮遊さ れた赤血球では，還元率は約30\%であるにすぎない，し かも完全に Hb に復元することはできなかつた。この一 連の実験中ウサギ赤血球でみられる血漿環境での特異性 はきわめて印象的であつた(第11図)。

\section{Fig. 11 Difference of Animal Species on} MetHb Reduction Rate (in vitro) (reaction period $3 \mathrm{hr}$ at $37^{\circ}$ )

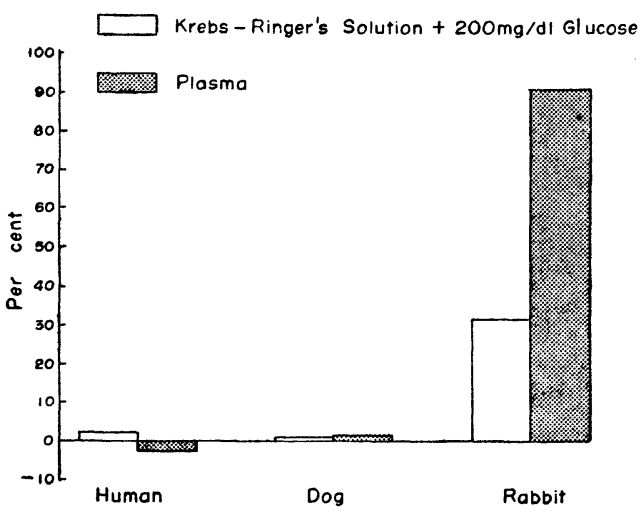

血漿環境とブドー糖リンゲル環境間のこの差異の理由 について検討した結果を示すと，

a) $\mathrm{Mg}^{++}$は解糖系䣼素中のへキソキナーゼ，エノラ 一访拉よび DPN 生合成の co-factor として必要である ことが知られている゙7。この金属イオンは通常のリンゲ 几液には含まれていない。そとで環境液に、Tyrode 液を 用いて同様に操作をし MetHb 還元能をブドー糖リンダ ル液と比較検討したが両環境間に差を見出すことはでき なかつた。

b）インシニリンが血糖をさげるのは直接または間接 にヘキソキナーゼ活性に作用しブドー糖の粼酸化を促進

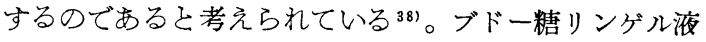


Kインシュリンを 1 単位 $/ \mathrm{ml}$ の割で加え, 従来のブド 一糖リンゲル液との差を比較したが，ここでも血漿効果 と関連のないことを確めた。

c）赤血球膜（礎質）には特異的コリンェステテラーセ が含まれて抢り ${ }^{399}$, 赤血球の酸素消費に対する糖効果が アセチルコリンで抑制されるという観察がある40)。そと で赤血球膜の基質透過性にアセチルコリンあるいはコリ ンェステラーゼがなんらかの形で関与するのではないか と考え, アセチルコリンおよびエゼリンを用いて Met$\mathrm{Hb}$ の還元能を観察したが，ブドー糖リンゲル液との間 には有意な差をみるてとはできなかつた。すなわち現在 まだ，血漿とブドー糖リングル液間のこの差を説明でき るょうな証拠は得られていない。さらに 2,3 重要な知 見を追加すると, ウサギ赤血球の還元能はヒト血漿を加 えてもかなり生ずるととを教室の峯岸 ${ }^{55}$ 法酸素消費の面 から示した。またウサギが連続舄血で貧血におちいる場 合，そのような赤血球を用いると，ヒトなどの赤血球と 同様還元はごく緩慢となる。その原因については目下教 室に捛いて引続き検討している。

\section{VII. ヒト, イヌ, ウサギ赤血球の MetHb 䢱元時,} 乳酸ならびに焦性ブドー酸の消長について

上記 MetHb 還元に用いたと同じ資料について,ヒト， イメ, ウサギ赤血球の MetHb 還元時の乳酸ならびに焦 性ブドー酸の消長について, ブドー糖リンゲル環境と血 墏環境とに分けて比較検討する。白柱はブドー糖リンゲ 儿環境を，黒柱は血漿環境をそれぞれ示す。反応時間 3 および 5 時間の測定値を平均し図示した (第12図)。

Fig. 12 Glycolysis of MetHb Cells

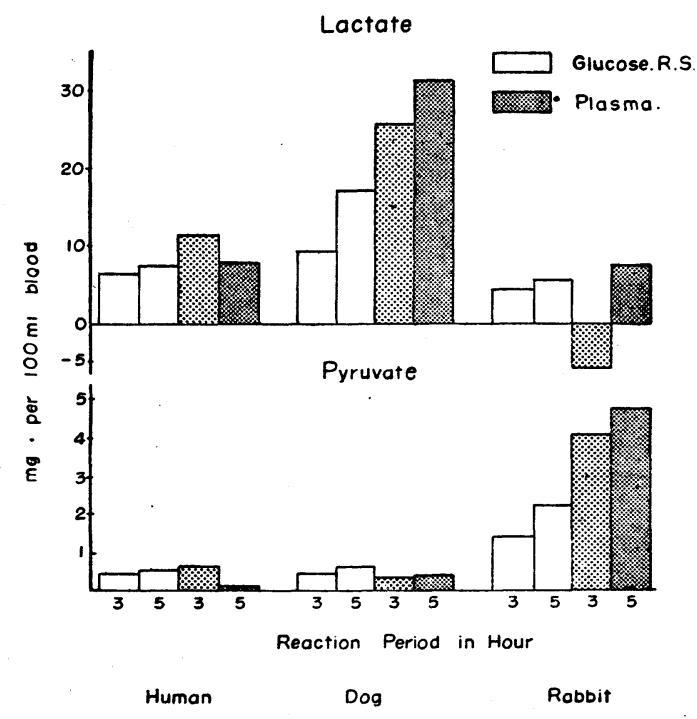

ヒト赤血球では乳酸は 3 時間 および 5 時間後に約 10 $\mathrm{mg} / \mathrm{dl}$ 前後の増量を示した。この量にはブドー糖リング ル液環境と血漿環境との間に特に差を見出すととはでき ない。焦性ブドー酸の増量は 3 時間値, 5 時間値のいず れも微量であり，てれまた環境差による生成量の差を見 出すことはできない。次にイヌ赤血球を用いた場合の成 績を示すとブドー糖リンゲル環境および血漿環境のいず れについても乳酸の生成はかなり旺盛であり, その増加 は 3 時間値よりも 5 時間値が大きく, 時間の経過と乳酸 の増加はかなり直線的関係を示している。これらの所見 ではイヌ赤血球の乳酸生成がヒト赤血球のそれと比較 して著しく高く, したがつてイス赤血球の解糖作用が七 卜赤血球のそれょりも旺盛であるかのような結果を示し ている。しかしての点ではイヌのみは血漿環境での実験 にアニリン拉よびニトロベンゼン中毒 MetHb 血球に関 する資料を用いて打り，乙の赤血球の MetHb 合量が前 述のごとく低濃度であつたというととを, この際考虑せ ねばならない。焦性ブドー酸の増加量はごく少く，したが つて時間的変化あるいは両環境の影響について, 特に差 はみられなかつた。これらの観祭は正常赤血球の乳酸, 焦性ブドー酸にみられる傾向とかなり類似していると とが知られる。すなわちヒトあるいはイヌ MetHb 血球 で解糖作用の特にこの間の変化は正常赤血球のそれとあ まり変らずに進行するのである。前項ではウサギ赤血球 の MetHb 還元能がきわめて活溌であることを明らかに した。乳酸の増加量は, 正常赤血球が両環境中で 5 時間に $20 \mathrm{mg} / \mathrm{d} 1$ 以上の乳酸を産生するという刘照実験と比較す るとかなり低值を示すのである。MetHb 還元が活湀に おこなわれている血漿環境では乳酸の還元は生成を上回 る。もし前もつて血漿中に比䡬的多量に乳酸を含むなら ば，その乳酸はょく MetHbの還元に利用されることを 示す。焦性ブドー酸は乳酸とは対照的に時間の経過と直 線関係をもつて增加する。との所見はウサギ赤血球に特 異的である。この観察から三炭桾燐酸脱水素酵素あるい は乳酸脱水素醉素作用で生じた DPNH が MetHb 還元 に利用されているととがわかる。ただし焦性ブドー酸の 生成量を MetHb 還元と分子量論的に論ずるにはいくつ かの障害を感じた。焦性ブドー酸の増加が血漿環境で著 しいととは明らかである。

\section{VIII. ウサギ赤血球の MetHb 還元ならびに解糖作 用に及ぼす PCMB の作用}

$\mathrm{PCMB}$ (パラクロールメルクリ安息香酸塩)は $\mathrm{SH}$ H基に きわめて親和性が高く, 低濃度でも容易に結合しメルカ プチードを形成する。その反応は可逆性であり, PCMB 
のS H基に対する作用はその到達性が高いことから蛋 白の “sluggish のSH 基”に対してょく阻害作用を 示 す，ある種醳素蛋白の活性にはこの“sluggish の SH 基”の存在が必要であるため本剤はすぐれた SH 䣼素 阻害戍として用いられる。PCMBによる阻害作用はグ ルタチオンで恢復するという ${ }^{41}$ 。

前記同様処理した MetHb 血球を $1 \times 10^{-3} \mathrm{M}$ PCMB 溶液で30分間 incubate したのち, ょく洗涤し, 以下血漿 環境中に $1 / 4$ 量の MetHb 血球として浮遊させ MetHb の還元と解糖作用学観察した。結果を 3 時間， 5 時間に 分けて図示すると第13図のとおりである。PCMB 処理 をおてなわない MetHb 血球と比較するに, 解糖系, 還 元系はともに強く阻害される。しかし解糖系の阻害が比 較的早く恢復してくること注 3 時間後の乳酸の生成量が 未処理の場合に接近することで明らかである。これに反 し還元系は強く阻害されるため恢復はなかなか及られ ず， 3 時間に初めて出現した。焦性ブドー酸の生成量は ほぼ還元と平行した。

Fig. 13 Inhibition of MetHb Reduction by PCMB (Rabbit)

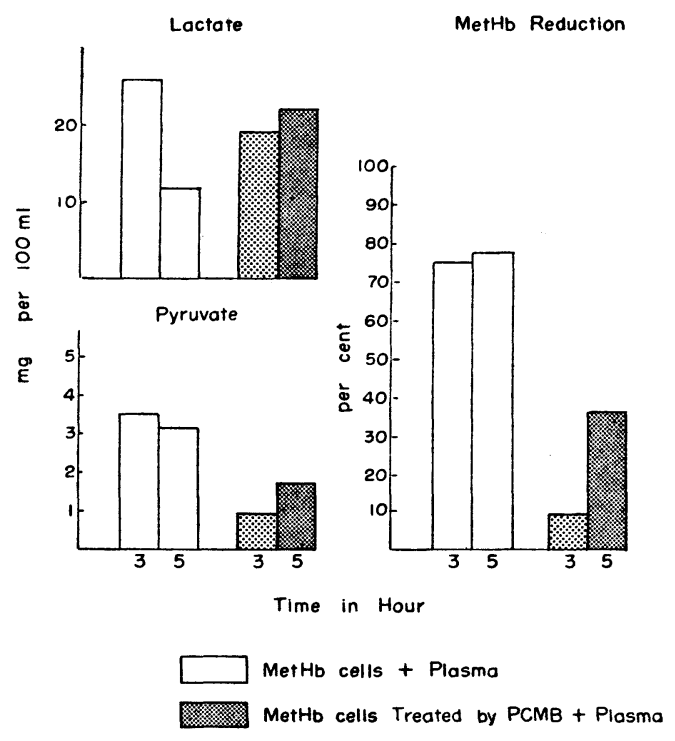

\section{考察}

MetHb の本態は 1924 年 Conant ${ }^{427}$ により明らかにさ れ，その後正常赤血球にも含まれることが知られてい る。ヒト赤血球中の MetHb 含有量沙約 $1 \%$ あ゙り ${ }^{43}$, こ のように正常赤血球中にも MetHb が含委れていること
は, 循環血液中に取入れられた種々の酸化剤あるいは代 謝産物が Hbを酸化し常にMetHbを形成しているためで あると考えられる。血液中に含まれる還元物質は MetHb を機能型に還元している。このために赤血球では著しく 左に偏した $\mathrm{Hb} \rightleftharpoons \mathrm{MetHb}$ 平衡が成立しているものと思わ れる。この還元機序に関係する物質として, アスコルビ ン酸,グルタチオンなどがまず考えられた。Marrison ${ }^{44}$ はグルタチオンが直接に MetHbを還元することを報告 して抢り，同じくチステインの還元作用についても報告 がある。特に前者は MetHb の還元が起きている際に減 少してくるという観察で支持されている。著者はよく洗 滌した MetHb 血球をリンゲル環境で incubate した際 に還元がまつたく起きないととを観察した。とのととは 赤血球中にはグルタチオンがかなり多量に含まれている のにも㧦らず，とのグルタチオンが症とんど利用され ていないととを示すものであり，さらにまた環境液中に グルタチオンを加えた場合でも還元を認めることができ なかつた。これらの所見から赤血球内に怙いて MetHb が還元されるのはグルタチオンの働きであると主張する 前記の著者の意見を支持するとといできない。次に血漿 中に含まれるアスコルビンの役割については, 主に $\mathrm{Hb}$ を機能的状態に保つためにあると考えている研究者が多 いが, 著者は MetHb 血球をアスコルビン酸加リンゲル 液中に浮遊させた場合，执ょび MetHbの溶血系にアス コルビン酸を添加した場合の実験を抗てなつた。アスコ ルビン酸を加えて打けば MetHbは還元される。しかし 間もなく $\mathrm{Hb} \rightleftharpoons \mathrm{MetHb}$ 系とアスコルビン酸きデハイド ロアスコルビン酸系とは平衡に達し還元はそれ以上進李 なくなる。 Lemberg ${ }^{251}$, Vestling ${ }^{46)}$, Gibson $^{47}$, Kiese $^{11 !}$ ? MetHb が多量である場合潘どアスコルビン酸による還 元は大きいとと,またそれ以上アスコルビン酸を大量加 えても MetHb 還元を促進することはないなどの観察を している。著者の実験では単にアスコルビン酸のみを加 えたものでは MetHbを完全に消失させることはできな いことを観察した。Brooks はウサギに亜硝酸塩を経静 脈的に投与し MetHb 形成させた場合にブドー糖の静 脈内投与は MetHb の還元を早めるととを認めて抢り， また Drabkin は赤血球内の MetHb が消失するのは血夜 中のブドー糖の減少汇関連するととを示唆している。赤 血球中にグリコーグンが存在しないというとと湾济確 実である。吉川 ${ }^{48}$ は $\mathrm{P}^{32}$ と濾紙クロマトグラフを用い, 赤血球中には糖代謝の中間物質としてブドー糖 6 燐酸, 果糖 1.6 チ燐酸, 2.3 チ燐グリセリン酸, 3 燐グリセリン゙ 酸, ATP, ADP が含まれるととを明らかにしている。 
Bartlett ${ }^{49}$ は $\mathrm{C}^{14}$ グルコースを用い短時間に $\mathrm{C}^{14}$ が乳 酸に移行することを見出し, 赤血球の比較的活溌 な解 糖作用を論じている。とれらの観察から筋肉同様に Embden-Meyerhof 系の存在することは確実である。そ の他赤血球には特に 2,3 チ粼グリセリン酸が多量に含 まれることが注目されている50)。ブドー糖 6 憐酸分解の もつ 1 つの系路である “oxidutive shunt”に関して 恃，Dickens ${ }^{511}$ はウマ赤血球から 6 燐グルコン酸抢よび リボース 5 燐酸脱水素醉素を発見して抢り，Francoeur 52) は溶血系中に非常に 活性な ブドー糖 6 燐酸脱水素酻 素， 6 燐グルコン酸脱水素䤃素の存在を 確証づけてい る。T C A 回路は 体細胞の呼吸系に打いては 不可欠の ものであるが 有核赤血球を 除いて，成熟赤血球にはミ トコンドリアを有して招らず，したがつて T C A 回路系 の醳素は存在しないと考えられている。しかしながら Spicer ${ }^{27}$ は MetHb 血球の環境液にフマール酸, 林樆 酸を基質として加える場合でも MetHb の還元が生ずる ことを報告して抢り，正常赤血球中には MetHb 還元の ため,とのような䤃素系が存在しているとも考えられる。 この点はまた有核赤血球の遗残醉素で示された所見であ るかもしれない。以上を通覧するに成熟赤血球の糖の分 解機序の大略虫次の之怙りである。

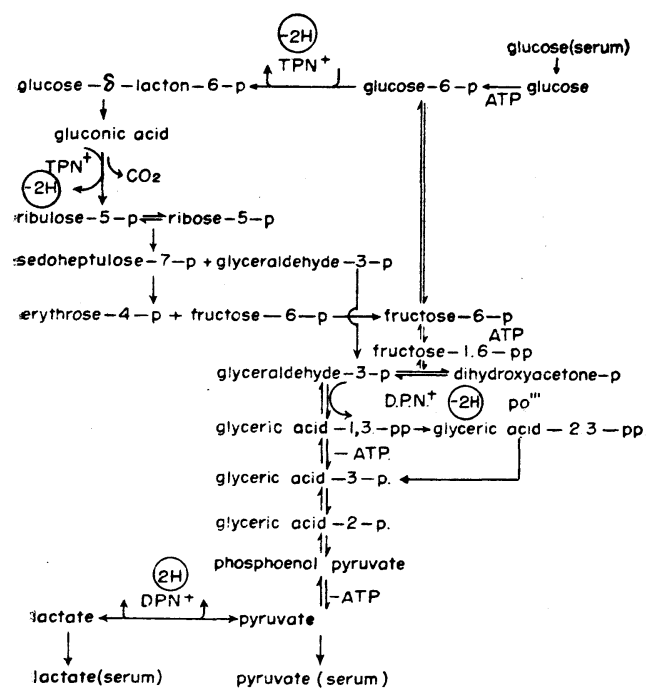

(p; monophosphate, D.P; diphospate)

環境夜中のブドー糖は赤血球膜を通過し血球内に入り ついでヘキソキナーゼにより燐酸化されブドー糖 6 燐酸 妀な。以下は Embden-Meyerhof 系で果糖 1.6 ヂ燐酸
となり，ついでグリセリンアルデヒド 3 燐酸とデオキシ アセトンに解裂する。グリセリンアルデヒド 3 燐酸は三 炭糖燐酸脱水素醭素の作用により燐グリセリン酸に酸化 され,この際, 共軛的に $\mathrm{DPN}^{+}$は DPNH に還元される。 正常赤血球の場合では，DPNH は焦性ブドー酸が 乳酸 に還元される際につかわれるためにその貯積が相殺され ているものと考えられる。ブドー糖 6 憐酸が “ oxidutive shunt "で酸化されるときには TPN+は還元されブドー 糖-ס-ラクトン 6 燐酸を生ずる。次にグルコン酸は $\mathrm{TPN}^{+}$ を還元しさらに脱炭酸されてリブロース 5 燐酸を生ず る。Kiese は Warburg \& Christian ${ }^{53)}$ が分離した “Zwischenferment”, あるいは Warburg, Christian \& Griese $^{54)}$ が赤血球から分離した TPNをへキソースモノ 燐酸とともに incubate したのでは MetHb の還元は非 常にわずかであることを観察し，彼が新たにウマ赤血球 から分離した co-factcr を含を成分は MetHb を還元す るととを確めとれを “Hämoglobin Reductase”と名

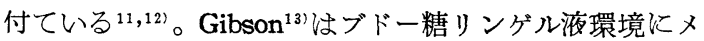
チレン青を添加すると MetHb 還元に伴なう燐グリセリ ン酸の增加は未添加の場合と比較しほぼ同じであるに拘 らず，MetHb の還元は著しく促進されると報告してい る。これらの研究者はいずれも MetHb 還元の際に“oxidutive shunt”の酵素がかなり重要な㗢をを有している と考えている。しかし正常赤血球で MetHb が還元され る場合のもつとも重要な還元作用は三炭糖憐酸から燐ク リセリン酸への酸化が起きるとき生ずる DPNH に基づ くものであるという考えを著者は支持している。この実 験は MetHb の還元と DPNH との関係を考察するため に MetHb の還元に際しこの乳酸と焦性ブドー酸の生 成量を測定した。これらの結果をみると, 赤血球内で MetHb の還元が盛んに起きているときは焦性ブドー酸 が増加しているが，このととは DPNH が MetHbを還 元するために利用されていることを示している。とれと は対照的に, ヒト, イヌ赤血球では正常赤血球の場合と 同様に乳酸注加してくる。しかしこれとは逆に焦性ブ ドー酸は增加しない。との際の MetHb 還元はきわめて わずかて 5 時間後でさえ核とんぞ羿めることができな い。前述したようにKiese は TPNH と MetHb間の酸 化還元にはさらに介在する因子の存在することを証明し て招り，Gibson ${ }^{131}$ は先天性メトへモグロビン血症患者血 球には DPNH と MetHb 間に必要な co-factor I が久 けているのであると考えている。著者はこの実験で，解 糖作用が旺盛であるというととが必ずしも MetHbの還 元を早めるのではないととを知りえた。例えば，MetHb 
が大量に形成されている場合でもかなり乳酸は增加して くるのであり，できた DPNH はごく一部分が MetHb の還元に利用されているにすぎないととが，乳酸と焦 性ブドー酸の生成量で推測できた。とれらの事実から DPNH と MetHb 間にはさらに必要な因子が存在し, その機能には一定の限界が考えられる。溶血系で還元が みられないというととは, 赤血球内の醭素系を知ろうと する面で著しく不利である。PCMB で処理した赤血球 では MetHb 還元が著しく阻害されることは, MetHb 還元機序に抢いて-SH 基の関与がきわめて 重要である ととを示唆している。PCMB 阻害からの恢復に際して は，末ず解糖系に恢復がみられしばらく遅れて MetHb の還元が現われてくるのである。峯岸 ${ }^{51}$ は PCMB 処理 赤血球の酸素消費が完全に抑えられるとと, 恢復にはか なりの時間を要するととを観察しており，これらの知見 吕ら考えると解糖系醏素に比較し MetHb 還元側飞必要 な醰素系が少いものと考えられる。Sivers \& Ryon ${ }^{561}$ はヒト赤血球を用い血漿環境と $0.85 \% \mathrm{NaCl}$ 環境で MetHb の還元速度を比較しているが，乙の場合に両環 境での差はみられていない。著者はウサギ赤血球の解糖 作用を血漿環境とブドー糖リングル液環境で観察し，両 環境の間に差のないととを站ている。しかし MetHb 血 球の場合の解糖作用は血漿環境では焦性ブドー酸が著明 に増加し，乳酸はかえつて減少の傾向を示している。一 方ブドー糖リングル液環境ではこのような変化がわずか みられるにすぎない。MetHb の還元速度は上記の傾向 と平行し，血漿環境では 3 時間後に実にその $90 \%$ が還元 される。血漿環境でのみこのように解糖作用と MetHb 還元の相互作用が合目的促進されるとと社注目すべき 所見である。

Lester $^{57)}$ あるいは Heubner ${ }^{581}$ は, 草食動物の赤血球 が MetHb の形成に対し非常に抵抗 の強いことを報告 しているが，著者はこれらの実験から，草食動物の赤血 球は還元能が大きいために形成した MetHb はすぐ還元 され，したがつて弱い MetHb 形成物質の投与ではなか なか MetHbをつくることができないのであると考えて いる。

\section{総括}

1）ウサギ血液に亜硝酸塩を添加すると MetHb が形 成される。この血液を $37^{\top} \mathrm{C}$ 恒温槽中で incubate すると 5 時間後 MetHb はすべて還元され $\mathrm{Hb}$ に戻る。しか しもしこの血液から血漿を除き，その代りとして環境夜 にリンゲルを加えると MetHb の還元はみられない。

2）血漿環境でみられるこの MetHb 還元ふ血漿中に
含まれるアスコルビン酸のような還元物質によるもので はない。

3）リンゲル液にブドー糖，乳酸を加えると MetHb の還元はやや進行する。

4） MetHb 還元機序における 血漿中のブドー糖, 乳 酸の意義を検討した。

a）醅母であらかじめ血漿中のブドー糖を分解して抢 けば未処理血漿の還元速度と比較し78\%阻害される。

b) $2 \times 10^{-3} \mathrm{M}$ モノヨード酢酸の添加は $55 \%$ 阻害す る。

c） $0.01 \mathrm{M}$ 弗化アンモニウムの添加性約 20\%阻㫪す る。

d）血漿にブドー糖をさらに添加しても還元速度は変 らない。

5）リンゲル，ブドー糖リンゲル，果糖 1.6 チ橉酸リ ンゲル, 血漿環境中で MetHb 血球をサポニンで溶血し, 礎質を除いた溶血系で実験するといずれも MetHb 還元 は現われない。DPN を様々な濃度で $200 \mathrm{mg} / \mathrm{dl}$ 果糖 1.6 于燐酸溶液に加え，乙の環境夜中で MetHb 血球を 溶血し礎質を除いたものを用いると MetHbの還元はい ずれも現われない。

6） ウサギ赤血球の好気的条件下の解糖作用をブドー 糖，乳酸，焦性ブド一酸の面から観察した。正常赤血球 の解糖作用を血漿環境と $200 \mathrm{mg} / \mathrm{dl}$ ブドー糖リングル環 境とで比較するに，乳酸と焦性ブドー酸の量からはその 差を認められない。赤血球が多量の MetHbを含んでい ると血漿環境下のブドー糖消費，焦性ブドー酸の增加は ブドー糖リンゲル環境と比較し著しく大きく，一方乳酸 の増加は抑えられる。

7）ヒト，イヌ，ウサギ赤血球の MetHb 還元速度 はウサギのみ速やかである。MetHb の還元が完全に進 むには環境液が血漿でなければならない。

8）ヒト，イヌ，ウサギ赤血球内の MetHb 還元の観 察と平行して，環境液中の乳酸と焦性ブド一酸の量を比 較すると, ヒトおよびイヌでは乳酸は増加し, 焦性ブド 一酸は増加してこない。ウサギでは焦性ブドー酸が目立 つて増加し，乳酸はやや減少する。

9）以上を総括すると,ウサギ赤血球のみは MetHbを 速やか消失することができるが，乙の性質を示すため には環境液は血漿でなければならない。解糖作用を障害 与るような操作を加えると還元は㧕えられる。MetHb 還元に伴ない焦性ブドー酸が増加することは, 三炭糖燐 酸と乳酸の酸化が一部利用されるととを示す。

10）この還元作用が PCMB のごとき S H基阻害阂 
で完全に抑制される点から，MetHb の還元機序にグロ ビンS H基が関与しその反応にあずかる役割は重要なも のと考える。

擱筆すると当 $\eta$, 御指導と御校閲を賜わつね竹村望助 教授に衾心より感謝の意を表します。

\section{文献}

1）折田頴 他：産科之婦人科, $23,1083,1956$.

2) Wintrobe: Clinical Hematology, 3 rd Edition, p. 146.

3）久保田重孝：最近の職業病， p. $178 ， 181,188$, 山水社, 1953.

4) Lian, C., Frumusan, P. and Sassier: Bull. et mém. méd. d. Soc. hop. de Paris, 55, 1194, 1939.

5) Deeny, J., Murdock, E. T. and Rogan, J. J. : Brit. M. J., 1, 721, 1943.

6) Hauschild, F.: Arch. f. exper. Path. u. Pharmakol., 184, 458, 1937.

7) Wendel, W. B.: J. Clin. Investigation, 18, 179,1938

8) Bodansky, O. and Gutmann, H. R.: J. Pharmacol. \& Exper. Therap., 90, 45, 1947.

9) Mangelsdorff, A. F.: Arch. Ind. Health, 4, $148,1956$.

10) Kiese, M. : Arch. f. exper. Path. u. Pharmakol., 204, 288, 1947.

11) Kiese, M. : Biochem. Ztschr., 316, 264, 1943.

12) Kiese, M. und Weis, B. : Arch. f. exper. Path. u. Pharmakol., 202, 493, 1943.

13) Gibson, Q. H.: Biochem. J., 42, 13, 1948.

14) Gutmann, H. R., Jandorf, B. J. and Bodanksy, O. : J. Biol. Chem., 169, 145, 1947.

15) Vierordt, K.: Die Anwendung des Spectralapparates zur Photometrie der Absorptionspektren und zur quantitativen chemischen Analyze Tuebingen, 1873, 16) より引用.

16) Michel, H. O. and Harris, J. S.: J. Lab. \& clin. Med., 25, 445, 1940.

17) Stadie, W. C.: J. Biol. chem., 41, 237, 1920.

18) Somogyi, M. : J. Biol. Chem., 160, 69, 1954.

19) Barker, S. B. and Summerson, W. H. :J. Biol. Chem., 138, 535, 1941.

20) Friedmann, T. E. and Haugen, G. E. : J. Biol. Chem., 147, 415, 1943.

21）藤井暢三：生化学実験法 定量篇，p. 420 , 南山 堂, 1956.

22) Bidmead and Watson: J. Clin. Path., 5, 30, 1952.

23) Borsook, H. and co-workers: J. Biol. Chem., 117, 237, 1937.

24) Ball, F. W. and Lehninger, A. L.: J. Biol. Chem., 194, 119, 1951.
25) Lemberg, R., Legge, J. W.and Lockwood, W. H. : Biochem. J., 35, 339, 1941.

26) Wendel, W. B.: J. Biol. Chem., 102, 373, 1933.

27) Spicer, S. S. and Clark, A. M. : J. Biol. Chem., 179, 987, 1949.

28）上代晧三 他：血色素の生理と臨床, p. 462, 医 学書院, 1958.

29) Haurowitz, F. : Biochemistry and Introductory Textbook (吉川春寿訳), p. 73, 朝倉書店, 1958.

30）吉川春寿：臨床医化学 I 実験篇, p. 148, 協同医 書, 1955.

31) Brooks, M. M. : Proc. Soc. Exp. Biol. and Med., 32, 63, 1934.

32) Cox, W. W. and Wendel, B. W. : J. Biol. Chem., 143, 331, 1942.

33) White et al. : Princisple of Biochemistry p. 423 McGraw-Hill Inc., 1954.

34) Shapot, V. S. : Biokhimiya, 3, 430, 1930.

35) Drabkin, D. L.: Federation Proc., 5, 132, 1946.

36) Tullis, J. L. et al. : Blood Cells and Plasma Proteins, p. 238, Academic Press Inc. N. Y., 1953.

37）大木幸介：細胞量子化学, p. 71, 南江堂, 1957 .

38) Haurowitz, F.：前揭書, p. 112

39) Tullis, J. L. et al. : 前揭書, p. 246

40) 本松深一：福岡医学, 46, 923, 1955.

41）平出順吉郎: SH の進歩, p. 53, 医学書院, 1954.

42) Conant, J. and Fieser, L. F. : J. Biol. Chem., $62,595,1924$

43) Bodansky, O.: Pharmacol. Rev., 3, 196. 1951.

44) Marnson, D. B. and Williams, E. F. : Science, 87, 15, 1938.

45) Duesber, R. und Koll, K. : Arch. exper. path, Pharmakol., 1162, 296, 1931.

46) Vestling, C. S. : J. Biol. Chem, 143, 439, 1942.

47) Gibson, Q. H. : Biochem. J., 37, 115, 1943.

48）上代哠三 他：前揭書, p. 462.

49) Bartlett, G. R. and Marlow, A. A. : J. Lab. chem. Med., 42, 178, 1953.

50) Guest, G. M. and Rapoport, S. J. Biol. Chem., 123, XIVII, 1938.

51) Dickens, F. : Biochem. J., 32, 1626, 1938.

52) Tullis, J. L. et al. : 前揭書, p. 229.

53) Warburg, O. und Christian, W. : Biochem. Ztsch., 242, 206, 1931.

54) Warburg, O., Christian, W. und Griese, A.: Biochem. Ztschr., 282, 157, 1935.

55）峯岸薰：日本鮞生学雑誌，13(4)，573, 1958.

56) Sivers, R. and Ryon, J. B. : Arch. Intern. Med., $76,299,1945$.

57) Lester, D. : J. Pharmacol. Exper. Therap., $77,154,1943$.

58) Heubner, W. : Arch. f. exper. Path. u. Pharmakol., 72, 240, 1913.

(受付: 1958 年 8 月 1 日, 特別揭載) 